\title{
DIE VERBAND TUSSEN SALUTOGENESE EN WERKORIËNTASIE
}

\author{
AM VIVIERS \\ F CILLIERS \\ Departement Bedryfsielkunde \\ UNISA
}

\begin{abstract}
Salutogenesis views stress not necessarily negatively in the workplace or in the private lives of man, but as an opportunity for optimasation which can lead to positive outcomes regarding stress and coping. The purpose of this research was to investigate the relationship between salutogenesis and work orientation as two constructs of optimasation. Factor and reliability analyses of questionnaire data $(\mathrm{N}=934)$, a correlation study and confirmatory structural analysis of latent variables were performed. A meaningful relationship between salutogenesis and work orientation was measured, but the findings also suggest independency. Interactively, the constructs seem to represent an optimal orientation in response to the bombardment of life and work stressors.
\end{abstract}

\section{OPSOMMING}

Salutogenese beskou stres nie noodwendig as negatief in die werksituasie en in die privaat lewe van die mens nie, maar eerder as optimaliseringsmoontlikheid ten einde positiewe stres- en coping-uitkomstes te bewerkstellig. Hierdie navorsing het ten doel die ondersoek na die moontlike verband tussen salutogenese en werkoriëntasie as optimaliseringskonstrukte. Faktor- en betroubaarheidsontledings is op vraelysdata gedoen $(N=934)$, korrelasies is bepaal en ' $n$ bevestigende struktuurontleding van latente veranderlikes is gedoen. ' $n$ Betekenisvolle verwantskap tussen salutogenese en werkoriëntasie is bevind, maar die bevindings dui ook aan dat die twee konstrukte onafhanklik staan. Interaktief blyk dit dat die konstrukte 'n optimale oriëntasie reflekteer in die hantering van lewens- en werkstressors.

Die konstruk salutogenese het die afgelope paar jaar al hoe meer bekendheid verwerf en navorsing word tans wêreldwyd daaroor gedoen. Die vader daarvan kan as Antonovsky (1972, $1979,1984,1987$ ) beskou word. In Suid-Afrika is werk oor salutogenese deur onder andere Strümpfer (1990, 1992, 1995) gedoen. Strümpfer (1990) het gespekuleer oor die moontlike verband tussen salutogenese en sekere aspekte van werk. Hierdie navorsing poog juis om te bepaal of daar wel 'n verband tussen salutogenese en sekere werkaspekte, waarna as werkoriëntasie (Viviers, 1996) verwys word, bestaan.

Salutogenese dui, volgens Strümpfer (1990), op die breë paradigma wat ondersoek instel na die mens se vermoë om stres te hanteer, gesond te bly en optimaliteit te bereik, te midde van die voortdurende bombardement van stressors. Salutogenese omsluit daardie inherente moderator veranderlikes wat as meganismes optree om die mens te laat cope te midde van stressors. Salutogenese verwys verder na optimaliteit in terme van die benutting van stres ten einde positiewe lewensuitkomstes te bewerkstellig. Die konstruk word verteenwoordig deur 'n aantal konsepte wat onafhanklik deur verskeie teoretici ontwikkel is, maar wel 'n salutogeniese onderbou het. Die drie belangrikste konsepte (volgens Strümpfer, 1990) wat in die ondersoek gebruik word, word kortliks verduidelik:

- Sin vir koherensie verwys (volgens Antonovsky,1987) na die mens se globale oriëntasie om sin te maak uit die eindelose stressors wat die mens konstant bombardeer.

- Persoonlikheidsgehardheidword volgens Kobasa (1979) vanuit 'n eksistensiële persoonlikheidsiening beskou as 'n globale persoonlikheidskonsep wat die stres-gesondheidverhouding modereer.

- Aangeleerde vindingrykheid word deur Rosenbaum (1980) omskryf as vaardighede en selfkontrole-gedrag wat die mens kan gebruik om redelike vlakke van stres op ' $n$ effektiewe wyse te kan hanteer.

Versoeke vir afskrifte moet gerig word aan A.M. Viviers, Dept Bedryfsielkunde, UNISA, Posbus 392, Pretoria 0003.
Werkoriëntasie as konstruk (Viviers,1996), verwys na daardie werkhoudings wat verband hou met onder andere, die mens as werknemer se ervaring, belewing en siening van sekere aspekte rakende sy werklewe. Werkoriëntasie word ook gesien as daardie aspekte van die werk wat verwys na optimalisering binne werkverband, en die uitleef van die werknemer se potensiaal om sodoende groei te bewerkstellig. Vir die doeleindes van hierdie navorsing word daar drie konsepte binne optimale werkoriëntasie ondersoek:

- Organisasieverbintenis dui, volgens Mowday, Steers en Porter (1979), op die mate waarin 'n werknemer verbind voel aan die organisasie wat aan hom werk verskaf.

- Werkbetrokkenheid dui volgens Lodahl en Kejner (1965) op die mate waarin werknemers sielkundig betrokke is by hul werk.

- Werkbevrediging dui, volgens Smith, Kendall en Hulin (1969), op die mate waarin werknemers algehele tevredendheid met die werk self ervaar, en ook met hul vergoeding, bevorderingsgeleenthede, toesighouding en medewerknemers.

Viviers (1996) dui in 'n omvattende literatuuroorsig daarop dat beide konstrukte vanuit 'n optimaliseringsraamwerk beskou kan word. Optimaliteit word soos volg gesien:

Optimaliteit in terme van salutogenese (Cilliers \& Wissing, 1993) verwys na die optimale hantering en verwerking van stres soos dit deur die mens in sy daaglikse bestaan ervaar word, dit wil sê die maksimale coping-gedrag wat deur die mens gegenereer word in sy hantering en verwerking van stressors. Optimaliteit in terme van werkoriëntasie verwys in hierdie navorsing na organisasieverbintenis, werkbetrokkenheid en werkbevrediging. Optimalisering in terme van genoemde drie konsepte, dui op die maksimale funksionering en assosiasie met die organisasie en die strewe na groei en die uitlewing van potensialiteite ten opsigte van werklewe. Uit bogenoemde beskouing blyk dit dat ' $n$ optimale oriëntasie ten opsigte van die hantering van die lewe, stres en werk, moontlik as gemeenskaplike faktor by beide konstrukte van salutogenese en werkoriëntasie gevind kan word. 
Die doel van hierdie ondersoek is om te bepaal of

- die konsepte sin vir koherensie, persoonlikheidsgehardheid en aangeleerde vindingrykheid die konstruk salutogenese verteenwoordig

- die konsepte organisasieverbintenis, werkbetrokkenheid en werkbevrediging die konstruk werkoriëntasie verteenwoordig

- daar 'n verband tussen die konstrukte salutogenese en werkoriëntasie bestaan.

\section{METODE}

\section{Hipotese}

Die volgende hipotese word vir die ondersoek gestel:

Salutogenese as konstruk, soos verteenwoordig deur sin vir koherensie, persoonlikheidsgehardheid en aangeleerde vindingrykheid, hou verband met werkoriëntasie as konstruk, soos verteenwoordig deur organisasieverbintenis, werkbetrokkenheid en werkbevrediging.

\section{Steekproef}

Daar is besluit dat die populasie so wyd moontlik gekies moet word ten einde so verteenwoordigend as moontlik van die werkende gemeenskap van Suid-Afrika te wees. Die populasie kan beskryf word as werknemers in enige beroep wat van oor die hele land afkomstig is en ook die verskillende kulturele groepe van Suid-Afrika verteenwoordig. Die steekproef wat uit die populasie gekies is, verteenwoordig al die studente wat in 1993 by Unisa in Bedryfsielkunde II geregistreer was $(N=1$ 983). Die steekproef is verder kultureel verdeel in 'n groep Blankes en ' $n$ Ander-groep wat Swartes, Kleurlinge en Asiate insluit.

\section{Meetinstrumente}

Meetinstrumente is geselekteer om beide salutogenese en werkoriëntasie as konstrukte te meet. Die battery bestaan uit drie vraelyste wat salutogenese meet en drie vraelyste wat werkoriëntasie meet. Die volgende meetinstrumente is gekies om salutogenese te meet:

- die Sin vir koherensie-vraelys (SOC) van Antonovsky (1987)

- die Persoonlikheidsgehardheid-vraelys (PVS) van Kobasa (1979)

- die Selfkontrole-skedule (SCS) van Rosenbaum (1980).

Heelwat navorsing is al oor die konsepte van werkoriëntasie gedoen en verskeie vraelyste is ontwikkel om elke konsep te meet. Vir die doeleindes van hierdie navorsing is instrumente geselekteer op grond van (Viviers, 1996)

- die feit dat die instrumente die twee onderskeie konstrukte se teoretiese onderbou ondersteun

- voldoende bewys deur verskeie navorsingsbevindings oor die geldigheid en betroubaarheid van elk

- die feit dat die keuse met kundiges op die terrein uitgeklaar is.

Die volgende meetinstrumente is gekies om spesifieke aspekte van werkoriëntasie te meet:

- die Organisasieverbintenisvraelys (OCQ) van Mowday, Steers en Porter (1979)

- die werkbetrokkenheidvraelys (JIQ) van Lodahl en Kejner (1965)

- die werkbevredigingvraelys (JDI) van Smith, Kendall en Hulin (1969).

\section{Dataverwerking}

Die vraelyste is by studieskole afgeneem en die tellings van die voltooide vraelyste $(\mathrm{N}=934)$, is statisties met behulp van die SAS- (1990) en LISREL- (Jöreskog \& Sorbom, 1993) rekenaarpakette verwerk. Ten einde ondersoek in te stel na die interne konsekwentheid van die onderskeie vraelyste vir toepassing in Suid-Afrikaanse omstandighede en spesifiek op die betrokke steekproef, is die ses vraelyste aan 'n faktorontleding onderwerp met die postulaat dat daar 'n relatief suiwer faktorstruktuur by elke vraelys en subskaal aanwesig sal wees. Die strategie wat in hierdie verband gevolg is, kan soos volg saamgevat word:

\section{Homogene groepe}

Volgens Nunnally (1967) is dit nodig om 'n steekproef, indien dit redelik heterogeen is, in meer homogene groepe vir die doeleindes van faktorontleding te verdeel. Volgens hierdie beginsel is die respondente in twee onderskeie groepe verdeel, te wete Blankes en Ander, met laasgenoemde groep wat Swartes, Kleurlinge en Asiate verteenwoordig.

\section{Faktorontleding}

'n Maksimumaanneemlikheids-faktorontleding is uitgevoer op al ses vraelyste vir albei groepe, naamlik Blankes en Ander. Die oplossings is aan die hand van verskeie metodes geroteer deur gebruik te maak van die SAS-pakket (1990). In die geval van die JDI is bogenoemde faktorontledings vir al vyf die subskale wat die vraelys uitmaak (werk, salaris, bevordering, toesighouding en medewerknemers), gedoen.

\section{Berekening van interne konsekwentheid}

Ten einde oor die interne konsekwentheid van die vraelyste en die subskale, daarom ook die betroubaarheid daarvan, te rapporteer, is Cronbach alfa-koëffisiënte vir elke vraelys en subskaal bereken en is ' $n$ kriterium gestel dat ' $n$ item wat nie ten minste 'n alfa-waarde van 0,50 oplewer nie, nie in die finale vorm van die vraelys gebruik word nie. Verder is daar ook ' $n$ itemontledlng gedoen om te kon vasstel of die onderskeie alfawaardes ' $n$ bydrae lewer of nie.

\section{Produkmomentkorrelasies}

Ten einde die verband tussen 'n salutogeniese oriëntasie en 'n werkoriëntasie te kon bepaal ooreenkomstig die doel van hierdie navorsing, is produkmomentkorrelasies bereken. Interkorrelasies tussen die onderskeie vraelyste en die subskale van die JDI is ook bereken. Daar is beslult om alle korrelasiekoëffisiënte met ' $n$ absolute waarde van 0,20 en groter, as prakties beduidend te interpreteer. Dit is veral van belang by Blankes waar die grootte van $n$ meer as 700 is, maar in die onderhawige ondersoek is dit ook as kriterium gebruik by Ander wat ' $n$ n van net groter as 200 het.

Pas van modelle met behulp van LISREL

'n Verband tussen salutogenese en werkoriëntasie is in die hipotese gestel. Die implisiete veronderstelling is dat 'n tweefaktorstruktuur die veranderlikes onderlê en dat hierdie twee faktore of konstrukte beduidend met mekaar korreleer. Die verwagting is dat hierdie resultaat bevind sal word vir beide Blankes en vir Ander.

Ten einde die twee latente of hipotetiese konstrukte te kan meet en die verband daartussen te kan bepaal, is 'n maksimumaanneemlikheids-faktorontleding op die veranderlikes uitgevoer en alle faktore met ' $n$ eiewaarde groter as 1 (die Kaiser-Guttmankriterium), is onttrek. Die faktoroplossings is aan die hand van die promax-kriterium ('n skuinsfaktorrotasie) geroteer ten einde interpreteerbaarheid te verhoog. Die skuinsfaktorrotasie is uitgevoer omdat verwag is dat die faktore (latente of hipotetiese konstrukte) met mekaar korreleer. Die gekorreleerde tweefaktor-hipotese is verder met behulp van die LISRELprogram ondersoek. 


\section{RESULTATE EN BESPREKING}

Vervolgens word die bevindings ten opsigte van die prosedure wat gevolg is bespreek, waarna die resultate van die navorsing gerapporteer en bespreek word.

\section{Faktorontleding}

Met inagneming van die kriteria wat vir die ondersoek gestel is, is die resultate van die faktorontleding ontleed. Die resultate van die aanvanklike faktorontledings wat op die afsonderllke vraelyste en hul subskale uitgevoer is, het getoon dat van die onderskeie subskale nie 'n suiwer enkelfaktor meet nie. Daar was in sommige gevalle meer as een faktor by ' $n$ bepaalde groep onttrek. Deurgaans het die scree-toets getoon dat die eiewaarde van die eerste faktor besonder hoog is, en onmiddellik ' $n$ afplatting toon wat alle verdere faktore betref en gevolglik op slegs een faktor dui. Sommige van die items het ook ' $n$ komplekse aard en verwantskap getoon en daarom is besluit om van 'n geforseerde enkelfaktor-ontleding gebruik te mak. Dit het deurgaans bevredigender resultate opgelewer. Slegs in die geval van een vraelys (die SCS) het die tweefaktorontleding beter resultate opgelewer, en word na die twee skale verwys as SCS1 en SCS2.

\section{Interne konsekwentheid}

By al ses die vraelyste is geen item, op grond van die kriteria wat gestel is vir die betroubaarheidsbepaling, verwerp nie. Die itemontleding het verder getoon dat al die items wel ' $n$ bydrae lewer.

Pas van modelle met behulp van LISREL

Die faktorstruktuur (regressiekoëffisiënte) wat vir die latente of hipotetiese konstrukte verkry is, word in tabel 1 weergegee.

TABEL 1

TWEEFAKTORSTRUKTUUR-OPLOSSING (GESTANDAARDISEERDE REGRESSIEKOEEFFISIËNTE) VIR DIE SALUTOGENESE EN WERKORIËNTASIE-MEETINSTRUMENTE

\begin{tabular}{lcccc}
\hline VERANDERLIKE & \multicolumn{2}{c}{ BLANKES $(\mathrm{N}=731)$} & \multicolumn{2}{c}{ ANDER $(\mathrm{N}=203)$} \\
\cline { 2 - 5 } & FAKTOR 1 & FAKTOR 2 & FAKTOR 1 & FAKTOR 2 \\
\hline JDI W & 0,75 & 0,07 & 0,72 & 0,13 \\
\hline OCQ & 0,75 & $-0,02$ & 0,56 & 0,10 \\
\hline JIQ & 0,64 & 0,11 & 0,50 & 0,20 \\
\hline JDI T & 0,59 & $-0,06$ & 0,75 & $-0,08$ \\
\hline JDI M & 0,48 & 0,05 & 0,66 & $-0,05$ \\
\hline JDI B & 0,45 & 0,08 & 0,59 & $-0,07$ \\
\hline JDI S & 0,16 & $-0,02$ & 0,29 & $-0,06$ \\
\hline SOC & 0,06 & 0,85 & $-0,08$ & 0,80 \\
\hline PVS & 0,06 & 0,55 & 0,20 & 0,56 \\
\hline SCS 1 & 0,12 & 0,38 & 0,14 & 0,18 \\
\hline SCS 2 & 0,13 & $-0,73$ & 0,12 & $-0,59$ \\
\hline
\end{tabular}

Die korrelasles tussen die faktore is 0,52 vir Blankes en 0,28 vir Ander.

Uit die resultate van tabel 1 blyk dat

- 'n tweefaktorstruktuur beide Blankes en Ander pas;

- die twee faktore duidelik as salutogenese en werkoriëntasie identifiseerbaar is; en

- die korrelasies tussen die faktore vir beide Blankes en Ander beduidend is.
Die ontledings wat uitgevoer is op die interkorrelasies van die meetinstrumente van salutogenese en werkoriëntasie, word in figuur 1 tot 6 gereflekteer.

Figuur 1 en 2 gee 'n diagrammatiese voorstelling van die model wat met behulp van LISREL getoets is, vir onderskeidelik die groepe Blankes en Ander. Hieruit blyk dit dat by Blankes en Ander beduidende korrelasies tussen salutogenese en al die

FIGUUR 1:

TWEEFAKTORMODEL VIR BLANKES: REGRESSIE-KOËFFISIËNTE

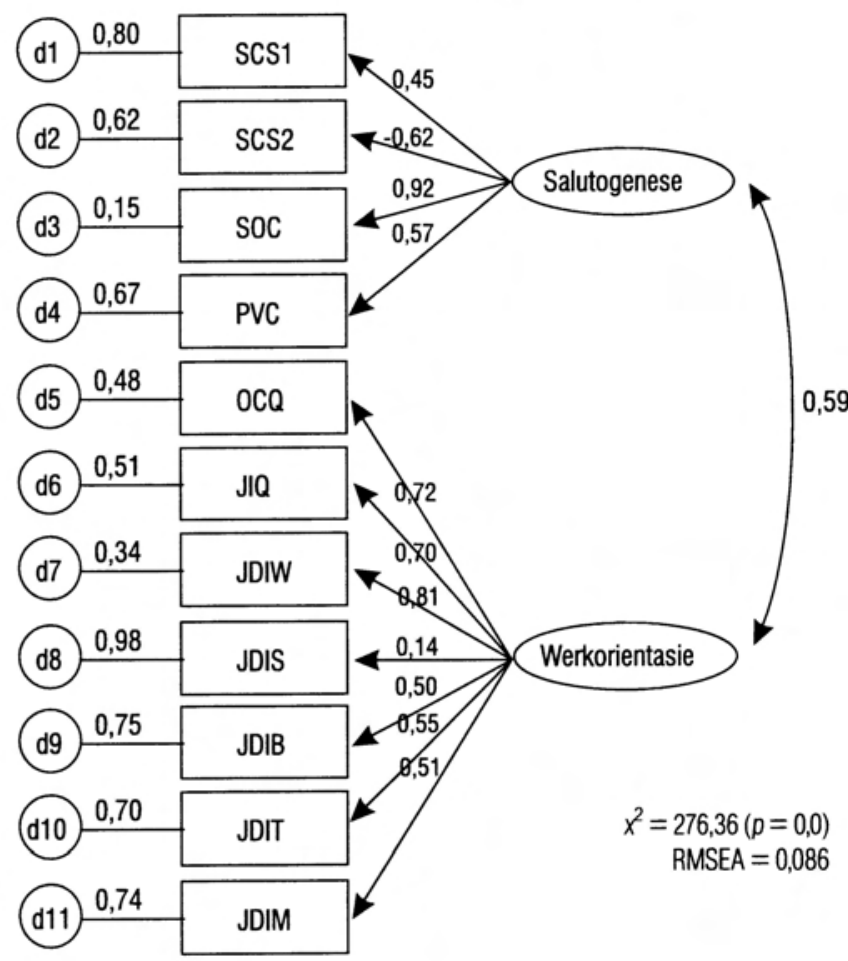

FIGUUR 2:

TWEEFAKTORMODEL VIR ANDER: REGRESSIEKOËFFISIËNTE

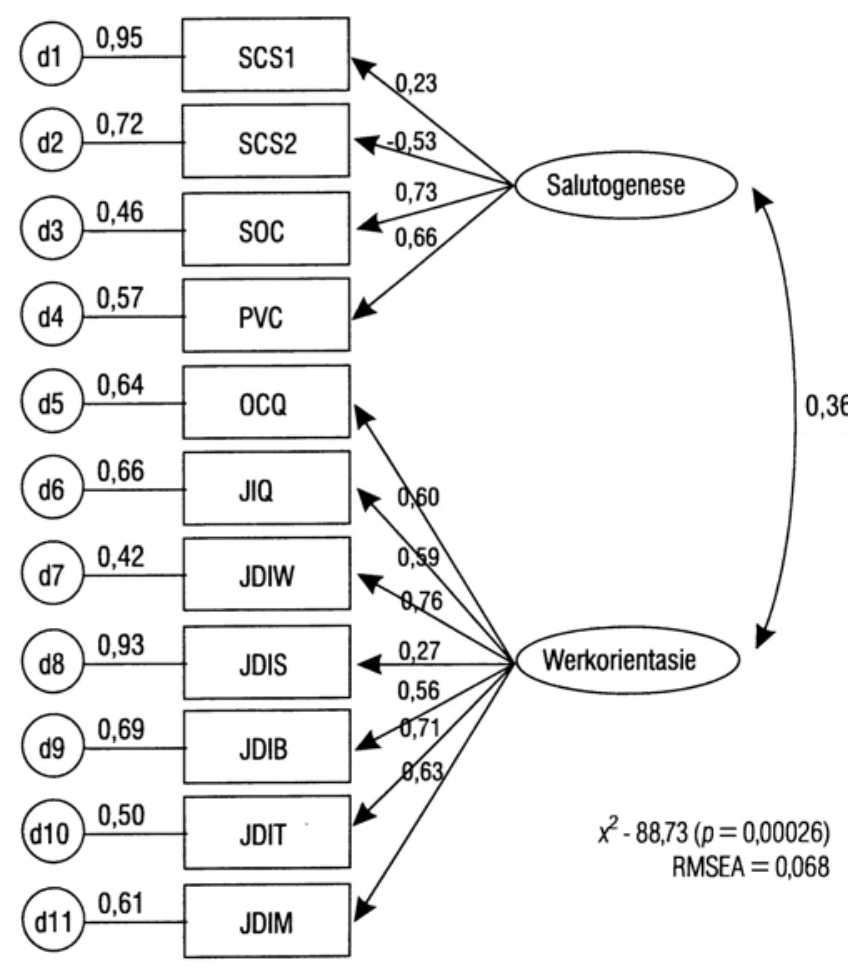


konsepte wat die konstruk verteenwoordig, gevind is. Dieselfde is ten opsigte van werkoriëntasie gevind, behalwe met die skaal JDIS wat by Blankes nie ' $n$ beduidende korrelasie opgelewer het nie. By die Ander-groep is die korrelasie beduidend, maar nie baie sterk nie. 'n Moontlike rede hiervoor kan wees dat die Suid-Afrikaanse gemeenskap oor die algemeen nie tevrede is met die vergoeding wat hulle ontvang nie en dat dit los staan van tevredenheid met werk in die algemeen. Uit bogenoemde bevindings blyk dit dat daar wel 'n beduidende verband is tussen salutogenese as konstruk en die konsepte sin vir koherensie, persoonlikheidsgehardheid en die twee subkonsepte van aangeleerde vindingrykheid, soos deur die faktorontleding bevind. Dit blyk verder ook dat daar wel ' $n$ beduidende verband bestaan tussen werkoriëntasie as konstruk en die konsepte organisasieverbintenis, werkbetrokkenheid en die subkonsepte van werkbevrediging, met die uitsonderlng van tevredenheid met salaris by Blankes. Vir alle praktiese doeleindes kan aanvaar word dat die drie konsepte wel werkoriëntasie verteenwoordig.

Figuur 3 en 4 gee die $t$-waardes vir elkeen van die regressiekoëffisiënte soos geskat deur die LISREL-program. Hierdie $t$-waardes stel die navorser in staat om te bepaal of die geskatte regressiekoëffisiënte wel statisties beduidend is. So is enige $t$-waarde groter as 2,5 (in absolute waarde) duidelik beduidend op ten minste die 0,01 vlak van beduidendheid.

Figuur 5 en 6 gee die program se voorstelle vir modifikasie van die model weer. Die modifikasie-waardes in hierdie figure gee die geskatte daling in Chi-kwadraat indien die voorgestelde verhoudings deel van die model gemaak word (Joreskog \& Sorbom, 1993). In figuur 1 en 2 word die Chi-kwadraat waardes asook die RMSEA-waardes gerapporteer. Laasgenoemde is ' $n$ soort 'populasiediskrepansie-funksie' (Bollen, 1987; Browne \& Cudeck, 1993; McDonald, 1989; Steiger,1990). Hoe nader aan nul hierdie waarde is, hoe beter pas die model. Gewoonlik word gepoog om hierdie waarde na aan of kleiner as 0,05 te kry (Browne \& Cudeck, 1993).

As figuur 1 tot 6 beskou word, blyk die volgende:

- Die model pas beter in die geval van Ander. Die RMSEA waarde is 0,068 vir Ander teenoor 0,086 vir Blankes.

- Aansienlik meer modifikasies word in die geval van Blankes voorgestel. Dit blyk veral dat daar heelwat korrelasies tussen die foutterme van die indikatore voorgestel word.

- By albei groepe is die korrelasies tussen salutogenese en werkoriëntasie beduidend. Die korrelasle is egter groter vir Blankes $(r=0,59)$, vergeleke met die van Ander $(r=$ 0,36 ). Die regressiekoëffisiënte tussen die latente veranderlikes word hier as korrelasies geïnterpreteer aangesien die latente veranderlikes in die model gestandaardiseer is.

- Die patroon van metings- en strukturele koëffisiënte Iyk vir die twee groepe redelik dieselfde. Oor die algemeen kan afgelei word dat daar wel gronde is vir die konseptualisering van twee konstrukte, naamlik salutogenese en werkoriëntasie en dat daar ' $n$ verband tussen hierdie twee latente veranderlikes bestaan op grond van die korrelasies wat verkry is. Daar is egter aanduidings dat die metings/ indikatore van hierdie twee konstrukte nie faktoriaal suiwer is nie - daarom die voorgestelde modifikasies deur die LISREL-program in figuur 5 en 6. Die moontlikheid bestaan om nog latente veranderlikes te postuleer vir beide die metingsmodel van salutogenese en werkoriëntasie. Daar moet in gedagte gehou word dat die faktorontledingresultate van die korrelasies nie meer as twee faktore met eiewaardes groter as 1,0 kon onttrek nie. Verder kan modifikasies soos voorgestel in figuur 5 en 6 , nie blindelings uitgevoer word nie. Die navorser moet teoreties verantwoording kan doen vir elke wysiging aan die model.
FIGUUR 3:

TWEEFAKTORMODEL VIR BLANKES: t-WAARDES VIR DIE REGRESSIEKOËFFISIËNTE

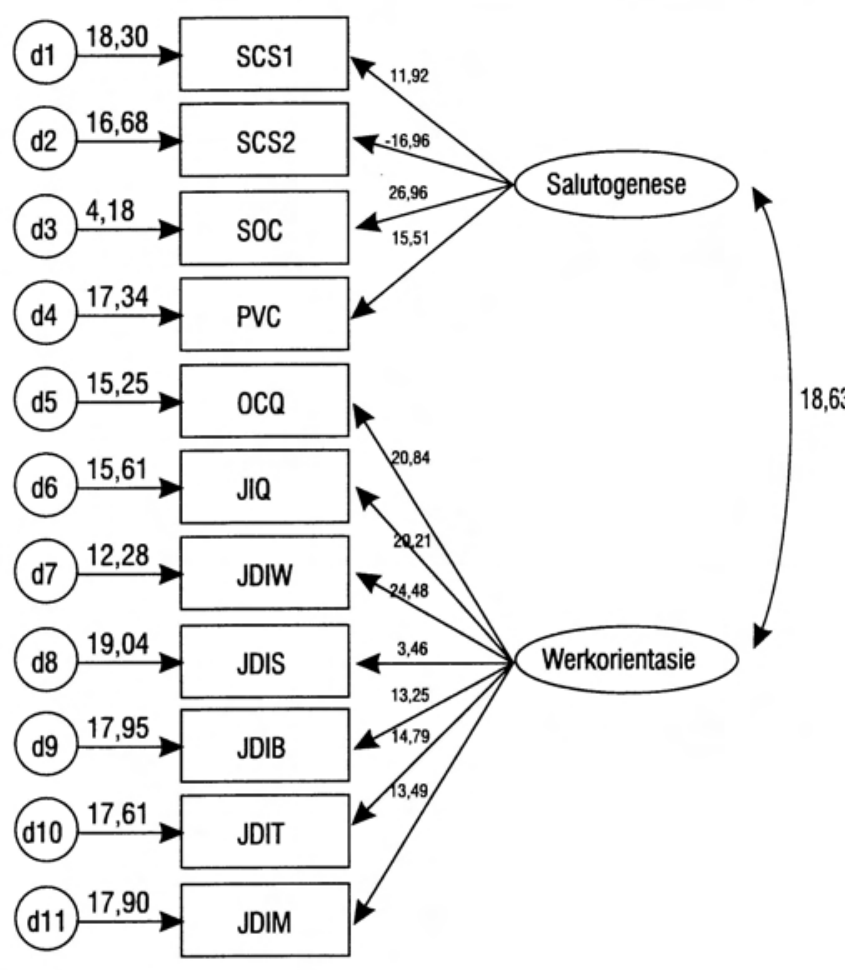

FIGUUR 4:

TWEEFAKTORMODEL VIR ANDER: t-WAARDES VIR DIE REGRESSIEKOËFFISIËNTE

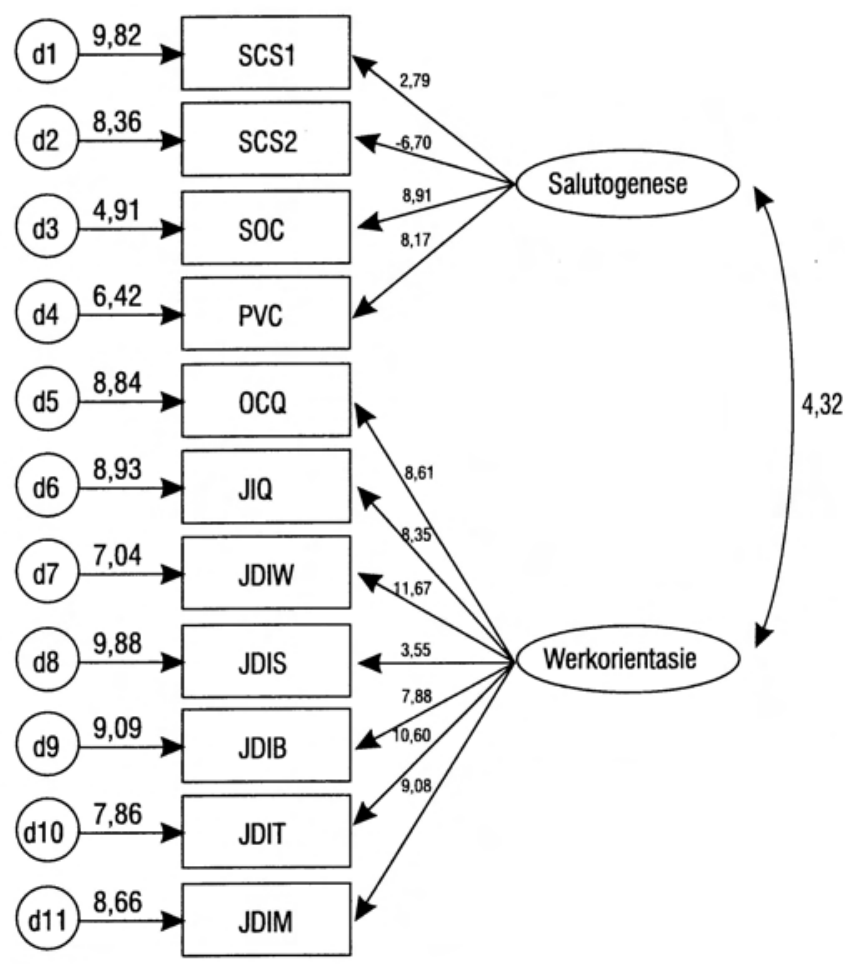


FIGUUR 5:

TWEEFAKTORMODEL VIR BLANKES: MODIFIKASIE-INDEKSE

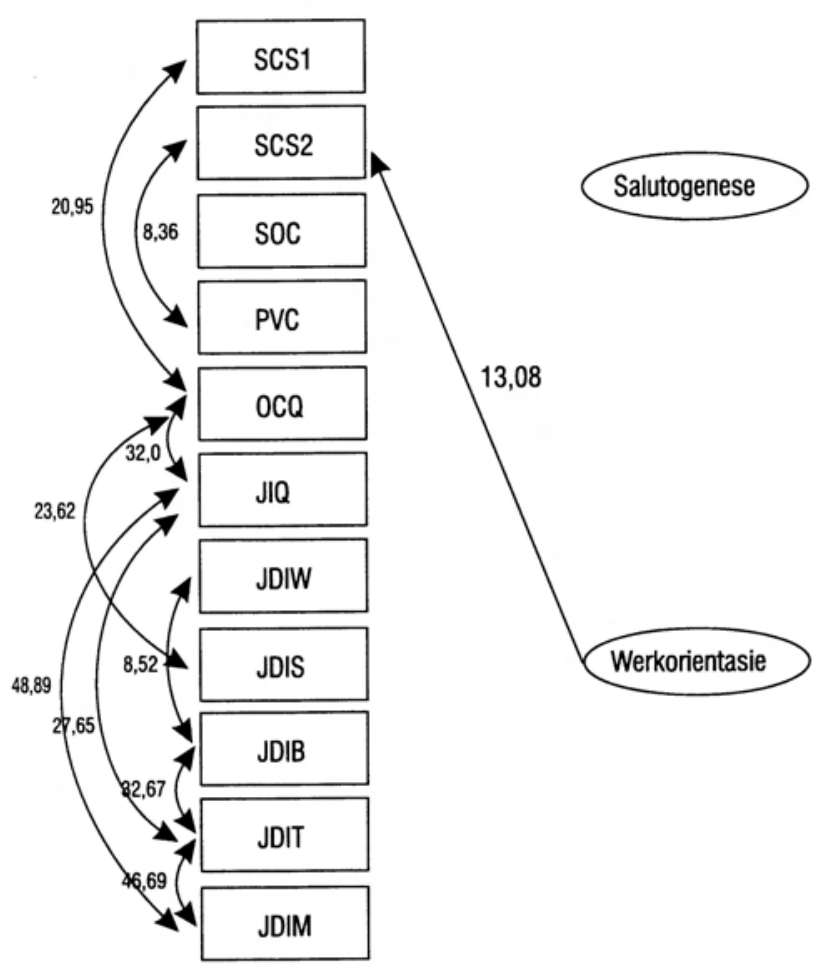

\section{FIGUUR 6: \\ TWEEFAKTORMODEL VIR ANDER: MODIFIKASIE-INDEKSE}

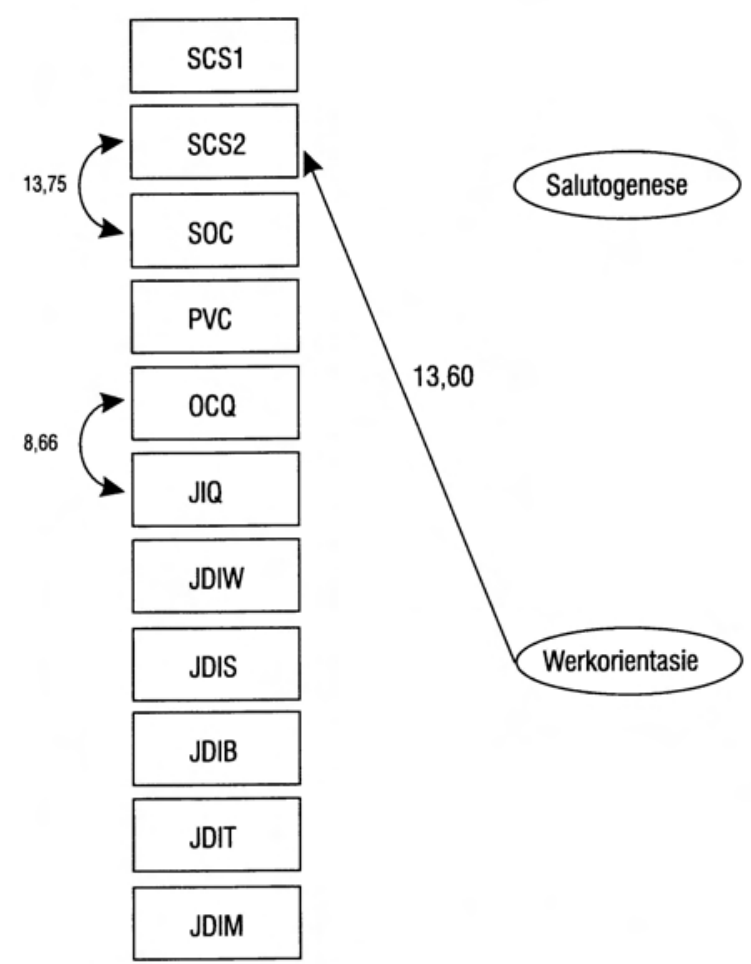

Opsommend kan gemeld word dat salutogenese en werkoriëntasie wel bestaansreg het as afsonderilke konstrukte, maar ook beduidend verband met mekaar hou. In die geheel word dieselfde model vir die Blanke- en die Ander-groep bevind.

\section{GEVOLGTREKKINGS EN AANBEVELINGS}

Salutogenese is duidelik deur die empiriese ondersoek geïdentifiseer as 'n selfstandige konstruk wat in die navorsing ondersoek is deur die insette van drie afsonderlike konsepte, naamlik sin vir koherensie, persoonlikheidsgehardheid en aangeleerde vindingrykheid. Werkoriëntasie is ook deur die empiriese ondersoek geidentifiseer as 'n selfstandige konstruk, wat in die navorsing ondersoek is deur die insette van drie afsonderlike konsepte, naamlik organisasieverbintenis, werkbetrokkenheid en werkbevrediging.

Die empiriese ondersoek het verder bevind dat daar ' $n$ beduidende verband tussen die twee konstrukte van salutogenese en werkoriëntasie bestaan. Hierdie bevinding steun die hipotese, naamlik dat daar ' $n$ verband tussen salutogenese en werkoriëntasie is. Dit kan toegeskryf word aan 'n gemeenskaplike aspek by albei konstrukte, naamlik optimalisering by die mens ten opsigte van die lewe en stres; en ook sy werk in die breë konteks. Die gevolgtrekking kan gemaak word dat salutogenese en werkoriëntasie verbandhoudend is en optimalisering verteenwoordig. Dit blyk uit die literatuur, sowel as uit die empiriese bevindings, dat die twee konstrukte afsonderlik gesien kan word, maar dat daar tog ' $n$ verband tussen die twee is. Daar kan dus gesê word dat die konstruk salutogenese wel 'n aparte bestaansreg naas die konstruk werkoriëntasie het, maar dat die twee konstrukte ook gemeenskaplik 'n optimale oriëntasie ten opsigte van werk en die lewe deel.

Vir toekomstige navorsing word aanbeveel dat ondersoek ingestel moet word of daar ander konsepte van salutogenese en werkoriëntasie is wat ook verbandhoudend is. Verder moet ondersoek word of soortgelyke verbande ook bevind word met ander steekproewe, veral indien die rassegroepe nie gekombineer word soos in hierdie ondersoek by die Ander-groep wel die geval was nie.

\section{SYNOPSIS}

\section{The relationship between salutogenesis and work orientation}

Salutogenesis is a relatively new paradigm in the study of stress and coping. Stressors can be experienced in a positive manner, but inefficient management of these stimuli tend to inhibit psychological health. The salutogenic approach views daily encounters as manageable reactions which generate positive outcomes and eventually optimal coping. Work orientation as a manifestation of working life experiences could be viewed as an antecedent for coping behaviour.

The purpose of this research was to investigate the potential relationship between salutogenesis and work orientation as constructs of optimal coping. Salutogenesis represents three concepts with theoretical underpinnings in work done by Antonovsky (sense of coherence), Kobasa (hardiness) and Rosenbaum (learned resourcefulness). Work orientation, in terms of optimal coping, was described as a manifestation of different psychological dimensions - organisational commitment (Mowday, Steers \& Porter) job involvement (Lodahl \& Kejner) and job satisfaction (Smith, Kendall \& Hulin).

The hypotheses state that:

(a) sense of coherence, hardiness and learned resourcefulness are significantly correlated to form a salutogenic construct;

(b) organlsational commitment, job involvement and job satisfaction are significantly correlated to form a work orientation construct; and

(c) salutogenesis and work orientation are independent, but significantly correlated, to form an integrated coping 
mechanism, reflecting an optimal orientation towards life and work.

A set of measures was distributed to a total of 1983 Industrial and Organisational Psychology students at the University of South Africa. Of the larger sample 934 responses were received from students who were economically active in full time jobs and proficient in the languages in English and Afrikaans. Due to the heterogeneous cross-cultural nature of the sample, factor and reliability analyses were performed on the measures and invalid items were rejected. The sample was also divided into a Whites and Other group. All questionnaires were found to be suitable for further analyses.

Spearman correlations (SAS program) within and between the salutogenic and work orientation constructs were determined and followed by a confirmatory structural analysis (LISRELanalyses) of the two latent constructs with their respective observed variables as measured by the questionnaires.

The results of the study showed that:

(a) sense of coherence, hardiness and learned resourcefulness are significantly inter-correlated and manifest themselves meaningfully from salutogenesis as a construct;

(b) organisational commitment, job involvement and job satisfaction are significantly inter-correlated and manifest themselves meaningfully from work orientation as a separate construct; and

(c) salutogenesis and work orientation should be regarded as independent, but related latent constructs.

The outcome applies to both the White and the Other group.

Salutogenesis and work orientation both represent an underlying movement on a continuum towards a more optimally functioning existence. In order to become psychologically fit in coping with the bombardment of demanding and negative stimuli, the individual needs to confront internal and external stimuli and handle the daily stressors in an effective manner. The mechanisms utilised by optimally functioning individuals enable them to manage stress effectively, which emerges as a potent source of creative energy, leading to a gratifying, 'optimal' life style.

\section{VERWYSINGS}

Antonovsky, A. (1972). Breakdown: A needed fourth step in the conceptual armamentarium of modern medicine. Journal of Social Science and Medicine, 6, 537-544.

Antonovsky, A. (1979). Health, stress and coping. London:
Jossey-Bass Publishers.

Antonovsy, A. (1984). A call for a new question - salutogenesis - and a proposed answer - the sense of coherence. Journal of Preventive Psychiatry, 2 (1) 1-11.

Antonovsky, A. (1987). Unraveling the mystery of health. London: Jossey-Bass Publishers.

Bollen, K.A. (1987). Structural equation modeling with latent variables. New York: Wiley.

Browne, M.W. \& Cudeck, R. (1993). Alternative ways of assessing model fit. In K.A. Bollen \& J.S Long (Eta), Testing structural equation models. Newbury Park: Sage Publications.

Cilliers, F.vN. \& Wissing, M.P. (1993). Sensitiewe relasievorming as bestuursdimensie: Die evaluerlng van ' $n$ ontwikkelingsprogram. Tydskrif vir Bedryfsielkunde, 19 (1), 5-10.

Jöreskog, K. \& Sörbom, D. (1993). LISREL version 8.12a vir WINDOWS.

Kobasa, S C. (1979). Stressful life events, personality and health: An inquiry into hardiness. Journal of Personality and Social Psychology, 37 (1), 1-11.

Lodahl, T.M. \& Kejner, M. (1965). The definition and measurement of job involvement. Journal of Applied Psychology, 49 (1), 24-33.

McDonald, R.P. (1989). An index of goodness of fit based on non-centrality. Journal of classification, 6, 97-103.

Mowday, R.T., Steers, R.M. \& Porter, L.W. (1979). The measurement of organizational Commitment. Journal of Vocational Behaviour, 14, 224-247.

Nunnally, C. (1967). Psychometric theory: Series in psychology. New York: McGraw-Hill.

Rosenbaum, M. (1980). A schedule for assessing self-control behaviours: Preliminary findings. Behaviour Therapy, 11, 109-121.

SAS (1990). Version 6, 4th edition. North Carolina: SAS Institute Inc.

Smith, P.C., Kendall, L.M. \& Hulin, C.L. (1969). The measurement of satisfaction in work and retirement: A strategy for the study of attitudes. Chicago: Rand McNally \& Company.

Steiger, J.H. (1990). Structural model evaluation and modification: An interval estimation approach. Multivariate Behavioural Research, 25, 173-180.

Strümpfer, D.J.W. (1990). Salutogenesis: A new paradigm. South African Journal of Psychology, 20 (4), 265-276.

Strümpfer, D.J.W. (1992). Psychological strength as point of departure: Fortigenesis. Address on occasion of receiving PASA award, Annual Congress, Psychological Association of South Africa, Stellenbosch, I October, 1-5.

Strümpfer, D.J.W. (1995). The origins of health and strength: From 'salutogenesis' to 'fortigenesis'. South African Joumal of Psychology, 25 (2), 81-88.

Viviers, A M. (1996). Salutogenese in organisatoriese konteks. Ongepubliseerde DCom proefskrif. Universiteit van SuidAfrika: Pretoria. 